\title{
Struggles of Underrepresented Girls as They Become Women: Understanding How Race \& Gender that Impact Personal Science Identity Construction
}

\author{
Donna Farland-Smith (Corresponding author) \\ Department of Teaching and Learning, The Ohio State University \\ 1680 University Drive, Mansfield, 44906 OH, USA \\ E-mail: farland-smith.1@osu.edu
}

Received: April 27, 2015 Accepted: June 1, 2015 Published: June 5, 2015

doi:10.5296/jei.v1i1.7501ＵRL: http://dx.doi.org/10.5296/jei.v1i1.7501

\begin{abstract}
This article looks broadly at the critical aspects involved in the "struggle" on different phases of one's academic life in order to observe how underrepresented girls take a variety of experiences with scientists and internalize them into their personal science identities. Some of the central struggles discussed are perceptions of scientists at crucial developmental times in relation to formal schooling. How do underrepresented girls feel in the science classroom? How do underrepresented girls feel with a teacher who is not their same race? Or a school that is dominated by white students and white teachers? How do underrepresented feel when textbooks favor White scientists and their accomplishments? An analysis about the understanding of how girls interpret "the struggles" at varying points of their lives introduces the importance of a multidimensional approach to understanding student perceptions of scientists and science is presented. This chapter will also the power of role models as a means of embracing the struggles underrepresented girls go through. As girls experience mentor scientists to shape their perception of those who pursue careers in science and what it is that scientists do.
\end{abstract}

Keywords: Underrepresented, Scientists, Perceptions, Science identity, Gender

\section{Introduction}

All children enter the education system with gender race and biases of their own based on their past experiences. These become part of their science identity from the youngest of ages. What follow is an excerpt from Noah the Little Scientist:

Noa is an average 6-year-old girl in the first grade. She has a mother and a father. Noa 
loves to read, write and explore the world. Her goal in life is to be a scientist and discover something great. Getting to school is an important part of doing well. This is why she gets up early, eats breakfast, and makes it to school on time. Her breakfast each morning before school is usually the same. Noa has something lightlike toast and fruit with a small cup of juice. On some mornings, Noa's mom will cook her a hot breakfast.

Shenell Bolden (2010) decided to write Noah the Little Scientist after being interviewed for a book focused on black women in the sciences. Because black women in science careers are rare, Bolden was asked to discuss her journey in school and why she stayed the difficult course in STEM pipeline, when so many others do not. Bolden wanted to influence girls who look like her not to be afraid to go into a science career and understand that there is no limit to what one can accomplish. She calls it "embracing the struggle".

\section{Literature Review}

The double jeopardy argument assumes an additive effect on two statuses -being female and being of a race that is underrepresented, Hispanic, and African American, etc. The tendency in science research has been to look at women or minorities and not examine variation within these groups. The additive argument does not acknowledge the fact that gender and race might interact to affect science outcomes in a positive way. Research on gender has primarily focused on the difference between girls and boys, with little focus on subgroups of women (Hanson, 2009). Hanson and Palmer-Johnson (2000) and Mau, Domnick, and Ellsworth (1995) concluded that not all women have the same experiences in science education and occupations. In fact, some data suggest that African American women are particularly interested in science, sometimes more so than their white counterparts (Hanson \& Palmer-Johnson, 2000; Hansen, 2004).

The National Science Board publishes the most current data on trends in science and technology in the United States (National Science Board, 2014). In order to focus on underrepresented women, we must first look at the broad picture of women's representation in Science \& Engineering (S\&E) fields. Women remain underrepresented in the S\&E workforce, although to a lesser degree than in the past. For example, from 1993 to 2010, growth occurred in both the proportion of workers with a highest degree in an S\&E field who are women (increasing from $31 \%$ to $37 \%$ ) and the proportion of women in S\&E occupations (increasing from 23\% to 28\%) (National Science Board, 2012).

It appears that as a country we are making progress attracting girls to high-level science and math courses (National Center for Education Statistics, 2009). Girls have also made gains in terms of performance when compared with boys at middle and high school levels (National Center for Educational Statistics, 2010). The National Center for Statistics (2009) shared these promising results, considering years of gender gap in the educational attainment of women, however, the number of girls who are training to become scientists and engineers remains low $(30 \%)$, while the number of jobs requiring science and engineering is growing. This suggests the problem may be deeper than merely selecting science courses or performing as well as boys on standardized tests, it suggests that young girls have especially vulnerable identities, and may believe that in order for someone to pursue a career in science 
they must identify with or possess negative stereotypical characteristics long before a career is formally considered.

National Science Board (2012) reveal that some gaps concerning Advanced Placements (AP) courses narrowed somewhat during the relatively short period of time from 2009 to 2011 . The white-black gap decreased from 36 to 34 points. The white-Hispanic gap fell from 30 to 26 points. The proportion of male and female students in the class of 2012 taking mathematics and science exams varied by subject. It becomes even more interesting when you start to exam students involved in Advanced Placements Courses. Black and Hispanic students were underrepresented among AP exam takers. Male students were more likely than female students to take advanced AP courses, including calculus BC (59\% versus $41 \%)$, physics B (65\% versus $35 \%$ ), and both physics $\mathrm{C}$ courses (about $75 \%$ versus $25 \%$ ). However, Female students were more likely than male students to take AP exams in biology (59\% versus $41 \%$ ) and environmental science (55\% versus $45 \%$ ). Black students made up about $15 \%$ of the 2012 graduating class, but they represented less than $8 \%$ of students taking any AP mathematics or science exam. Hispanic students made up about $18 \%$ of the class of 2012 , but their representation among AP exam takers ranged from a high of $15 \%$ for environmental science to a low of $8 \%$ for calculus $\mathrm{BC}$ and $7 \%$ for physics $\mathrm{C}$ : electricity/magnetism. The gap between low- and high-performing students dropped from 89 to 87 points.

Performance disparities in mathematics and science were evident among different demographic groups at grades $\mathrm{K}, 4$, and 8 . Some score gaps narrowed over time, however. At grades $\mathrm{K}, 4$, and 8 , students from low-income families or homes where the primary language used was not English had lower mathematics and science scores than their peers from more advantaged backgrounds (National Science Board, 2012). Black, Hispanic, and American Indian or Alaska Native students performed substantially lower than their white and Asian or Pacific Islander counterparts. Gender differences in achievement were generally small and favored boys in most cases. Among black students, however, girls performed better. Some gaps in mathematics narrowed over time at grade 4. Between 1990 and 2011, the score gaps decreased between white and black students (from 32 to 25 points) and between low- and high-performing students (i.e., at the 10th and 90th percentiles) (from 82 to 73 points) (National Science Board, 2012).

Despite these improvements, girls are not navigating their ways into science careers. The problem occurs when girls, at a young age, form perceptions about the human aspects of the sciences that are narrow and limiting, and, as a result, are unable to identify with science professions (Buck et al., 2007). Unfortunately, this results in young girls who are qualified and capable becoming discouraged from considering science fields.

The most vulnerable population continues to be middle-school girls, as they are especially sensitive when constructing their own identities. It appears that negative perceptions surface in the fifth through eighth grades, often times limiting girls' pursuit of career choices in the areas of science and technology (Erb, 1981). For example, in the U.S. many students, especially females, choose to end their study of science after one or two years of required courses (Scantlebury \& Kahle, 1993). We know that girls are unlikely to begin to value 
activities that do not match either their social identities or their personal identities (Buck et al., 2007). Therefore, it is important to consider the conditions in which girls begin to "like" science and value its members (scientists). Brickhouse and Potter (2001) identified that having a science or technology-related identity does not mean that one will necessarily succeed in school. If that science-related identity does not also reflect the values of the school-mediated engagement, or if the students do not have access to the resources they need to do well in science, they may not succeed.

\subsection{Science Identity}

Gender is one important part of identity, but not the only part. One's science identity, as defined by Carlone (1994) demonstrates competent performance in relevant scientific practices with deep meaningful knowledge and understanding of science, and recognizes oneself and gets recognized as a science person by others. The construction of this identity requires the participation of others as it is constructed socially within communities of practice (Tan \& Calabrese Barton, 2007). Lave and Wenger (1991) concur students develop identities through engaging with the practices and tasks of the science class upon entering a community of practice such as the science classroom. Learning science in this community then becomes "a process of becoming to be, of forging identities in activity" (Lave \& Wenger, 1991: p. 3).

A person's identity is always in continuous development, even if a person has relatively stable perception of "who" one is. For example, Giddens (1991) discussed the circumstances of new knowledge and new experiences, people constantly reconsider and redevelop their self. Some choices people make and are continuously made and remade on a daily basis might be clothing, physical appearance, leisure activities, music, sports, sexuality and beliefs (Giddens, 1991). How does this relate to the science classroom? As underrepresented girls encounter school and the context of the classroom they are defining and expressing themselves by subject preference and classroom behavior (Lyng, 2004). Carlone and Johnson (2007) view science identity as how women make meaning of science experiences and how society structures those possible meanings. The community of practice is dependent on environmental factors inherent within that community as it is accepted that these identities are fluid and subject to change.

According to Brickhouse and Potter (2001) having a science or technology-related identity does not mean that one will necessarily succeed in school, if that science-related identity does not also reflect the values of the school-mediated engagement or if the students do not have access to the resources they need to do well in science. However, successful participation in school science, despite the lack of resources in a home environment, can be better facilitated when students have a science-related identity they can draw upon. If science identity in consideration of attitudes, feelings, and intellect is embedded within a particular context, such as a community of practice, the term personal science identity is based on the introspective nature of one's science identity or the internal interactions within oneself, as defined by the Farland-Smith (2009). One's personal science identity is embedded within his or her science identity of his or her identities-in-practice. The identities-in-practice is the result of the external features one can see, such as classroom participation, etc. The personal science 
identity is deeper in magnitude, and is the sum of all experiences in science. One way in which this internalization is communicated is through the pictures girls draw about scientists. It is important to discriminate between science identity and personal science identity, the difference being internal reactions versus external actions. Identity construction is composed of science identity that is exhibited and revealed to others in a social setting. One's personal science identity may never be fully revealed to others, because it houses all the experiences with science and scientists. The likes and dislikes, whether they have an opportunity to rise to the surface or not, are dependent upon the community of practice and opportunities, including a person's self-efficacy and comfort level with science. For example, a female may like something and not know why or what situation informed her choice.

All students engage in identity work while participating in science, whether purposefully or not (Tan et al., 2013). According to Tan et al. (2013) this identity work of young girls in science is grounded in both the positions individuals are assigned (or take on) as well as the tools, relationships and practices available within the communities where they engage science.

\subsection{Stereotypic Threat}

Similar to the larger literature on minorities and education systems, there is evidence that the "stereotype threat" works against young minorities in the sciences (Swarat et al., 2004). Thus, young African American women's responses to negative stereotypes about the abilities of women and African Americans in science might be daunting and sometimes deliberating factor in their pursuit of science (Hanson, 2009). In math, one possible explanation for some persistence of the gender gap is directly related to this phenomenon (Steele \& Aronson, 1995). According to this idea in relation to math performance, a women's abilities are disrupted under in this environment not because they lack talent for the subject but because they feel threatened by the possibility that their performance will confirm the negative stereotype associated with that group (Cadinu et al., 2011). However, stereotypic threat can also work the other way, Carlone (2004) reported that in a study with upper middle class girls who were mostly concerned with accessing and maintaining a good student identity (rather than connecting to science in any meaningful way) and resisted promoted meanings of science and scientist that they perceived as threatening to their good student identities. For science instruction, the National Science Board (2012) frequently cited problems included inadequate funds for purchasing equipment and lack of science facilities. At the elementary level, more than one-quarter of program representatives reported insufficient time to teach science as a serious problem for science instruction.

\section{Struggles of Science Identity Construction during Early Childhood Years}

Underrepresented females from the youngest ages face a struggle in which they must negotiate without even being aware. Young people are absorbing all kinds of the education system's messages about race and gender (Hanson, 2009). There is substantial evidence that a mother's educational and occupational resources have an impact on daughter's behaviors and aspirations (Mau et al., 1995). This influence may be stronger in black versus white (Maple \& Stage, 1991). White women are two times as likely to have a mother with a college education 
and to have a father in a professional occupation. Surprisingly, there is no difference between the two groups of young women on whether their mothers workers in a professional occupation. When a mother has a college degree it increases the odds that her daughter will have science in college. For example, parents may reinforce the belief that science is a male subject by explicit messages i.e., comments regarding gender abilities or their own past abilities. However, they are also sending implicit messages about in their purchases of toys and games (Tomasetto, Alparone, \& Cadinu, 2011). Therefore, books like Meet Noa as described in the earlier part of this chapter are created to convince underrepresented girls from the youngest of ages that they can be scientists.

Regrettably, many students at an early age form perceptions of scientists and science that are narrow, inappropriate and inaccurate (Barman, 1997; Chambers, 1983; Finson, 2002; Fort \& Varney, 1989; Mead \& Metraux, 1957; Schibeci \&Sorenson, 1983). Chambers (1983) revealed that older elementary students included more indicators of stereotypical images in their illustrations, than did five- to seven-year-olds, suggesting that by fourth and fifth grades, students already have formed their limited views of who a scientist is. These inaccurate views of scientists are widely held by students from elementary through secondary school (Barman, 1996; Chambers, 1983). L. D. Newton and D. P. Newton (1998) found in six years of research with having children draw pictures of scientists that the stereotypical, male images of white men in the laboratory increased with age. Therefore, the most females and most minorities portrayed in the pictures are drawn at the youngest of ages, meaning the pictures that portray the least stereotypes are drawn by the youngest children (Farland, 2006). In the examination of gender differences, only girls draw female scientists and the majority of the female scientists are drawn by Kindergarten to second grade students, meaning children are less aware of the gender stereotypes associated with scientists at the youngest of ages (Farland, 2006). Parents, teachers and school administrator shave unknowingly provided experiences for children that lead them away from, rather than toward, rich and rewarding experiences in science (Farland-Smith, 2009).

\section{Struggles of Science Identity during Middle School Years}

Underrepresented females in middle school face a different struggle, one in which they begin limiting their personal career choices (as early as fifth grade) in the areas of science and technology (Erb, 1981). This is because during this time of adolescence girls are developing their identities and they either accept or reject because their identities are in continuous development and constantly change as they reconsider and redevelop themselves (Giddens, 1991). It is commonly accepted that students categorize occupations based on gender, which affects the range of possible careers from which they choose (Gettys \& Cann, 1981). Several studies have found that students' subject interest is the key factor in educational choices, like selecting a career (Angell Henriksen, \& Isnes, 2003; Lindahl, 2003). However, we also know that just because someone is interested in a subject it does not mean that they will necessarily select that subject as a career, especially young women (Storen \& Arnesen, 2003). Several researcher have found that in science education, girls, especially non-White girls do not identify with science even if their achievement is high (Archer et al., 2013; D. Sadker, M. Sadker, \& Zittleman, 2009). And so the importance of understanding the complexities and 
formation of girls' science identity is critical.

\section{Struggles of Science Identity during High School Years}

Underrepresented females in high school face a different struggle, one in which they must negotiate being "invisible" in science classes. The more masculine stereotyped the course is, the greater the probability that girls will avoid participation or exhibit poor performance (Brickhouse, Lowery \& Schultz, 2000). Many authors referred to this reality of being invisible as 'alienation'. For example, peer pressure and feedback are particularly relevant given the focus on science education in the high school years. It is during this time that the young person is forming their identity and feedback from peers is one of the strongest influences for youth. It is this identity and feedback from peers that is one of the strongest influences for youth. It is this identity (so heavily influenced by the attitudes and feedback of peers that will be an important element in predicting success or failure in school science (Sadowski, 2003). They really don't talk about black scientists unless it's black history month, and if you go to school where there's mostly whites in your class how are you supposed to feel like you belong?

Some girls like science but make it clear they would not like a career in science. Some have argued that since women perform less well in science than men, and minorities do less well than whites, there will be a double disadvantage for you African American women in science (Clewell \& Anderson, 1991; Cobb, 1993; Vining Brown, 1994). Findings from NELS data show that in the area of science course-taking, there are often no differences between white women and African American women. Where there are differences there tends to be an African American advantage. Although data on science achievement shows a clear white advantage on most indicators, eight years out of high school the African American women are more likely to report a job in science. Similarly, findings on science attitudes show a distinctly positive attitude toward science on the part High School underrepresented females in science majors face a different struggle, one in which they must negotiate being "invisible" in science classes. Hanson (2009) noted the strong interest in science shown by young African American women that was discovered in earlier research (Hanson, 1996; Hanson \& Palmer-Johnson, 2000). Textbooks and teachers focus mainly on science knowledge and inventions created by white scientists. Hence, they are seldom made aware of the contributions of African Americans (much less African American women) in science (Ovelton Sammons, 1990; Von Sentima, 1985). Role modeling, self-confidence building, and providing a sense of belonging are also important for minority youth in the science classroom (Hoyte \& Collett, 1993). Many of these strategies are not normal parts of high school or undergraduate science classes and programs. Yet these strategies, together with a diverse faculty and a school system that encourages faculty development on these issues, are key to promoting success for racial minorities in the science classroom (Hoyte \& Collett, 1993).

\section{Struggles of Science Identity during Undergraduate and Graduate Years}

Undergraduate underrepresented females in science majors face a different struggle, one in which they must negotiate a culture characterized by white masculine values (Eisenhart \& Finkel, 1998; Johnson, 2001; Nespor,1994; Carlone \& Johnson, 2007). For example, Carlone 
and Jonson (2007) discussed women's talk is affirmation-seeking and giving; when women do not receive affirmation, interaction may be strained, uncomfortable, and or alienating (Eckert \& McConnell-Ginet, 2003; Tannen, 1994). At this level, the professor's silence, whether intended or not, could be interpreted as a masculine test, requiring credible performance in the absence of this feedback or affirmation (Carlone \& Johnson, 2007). Glenn (2004) in research about cross-gender communications support the motion of silence playing a masculine testing role. Russell and Atwater (2005) found that strong pre-college science experiences, family support, teacher encouragement, intrinsic motivation, and perseverance were all critical factors in underrepresented men and women success.

\section{Discussion}

Attracting underrepresented women in science is not a new idea. We have long since known that once we lose girls become disinterested in science, they tune out possibilities for science-related careers. Perhaps what we did not realize before now, is the many struggles underrepresented girls face throughout their academic career. For example, take Noa, if someone has a healthy perception at age 6 will it remain intact when self-selecting careers during the middle school years? If it does, will it remain healthy and vibrant if silenced and alienated in high school classrooms? Many researchers discuss one struggle, as an excursion, but when in reality, many underrepresented girls face many struggles at various stages. This chapter looks across those stages to pose some important questions. By analyzing research that is organized to examine many years of one's life (like the ages 6-36), we see there are many struggles women, especially underrepresented women encounter and if they overcome the current struggle there is yet another lurking at the next developmental stage of their academic career. Could it be that underrepresented women become downtrodden by the consistent attacks against their science identity? Or is it that they get strengthened by these attacks and more resilient? If women, including underrepresented women do not encounter positive role models of positive teachers in science, they are much less likely to fathom a career in science, because they do not want to fit into the stereotype. Thus, suggesting the impact role models can make on an underrepresented girls' science identity. Pearson (1986) notes that many white teachers have never seen African American scientists and engineers. African American students have few role models in science, since they may not have access to African American science teachers (or African American scientists in the curriculum). African American students have few role models at school and are especially important for African American youth given the fact that many do not have parents and relatives were scientists (Thomas, 2007).

The data collected over four years at a summer science camp suggest guiding educators towards selecting, preparing, and maintaining successful interactions between middle-school girls and working scientists (Farland-Smith, 2009). A science camp was demonstrated as an established transformative experience for young female students, broadening their perceptions about scientists (Farland-Smith, 2009). For example, at a five-day summer camp designed for middle-school girls $(\mathrm{N}=50)$, fifth through ninth-grade students were able to identify with individual scientists and learn more about the science field. Data from the girls' journals, pictorial representations, and field notes demonstrated that these young women 
related to scientists who actively engaged them in hands-on, problem-based activities and had a sense of humor while doing so. Girls closely identified with science fields that offer an opportunity for travel and for interaction with animals. In addition, it is evident that the girls' personal and social interactions shaped their perceptions of scientists and helped them internalize their experiences as members of a science community in relation to their overall science identities (Farland-Smith, 2012).

Carlone and Johnson (2007), and Lewis (2003) agree that the nature of science identity is socially constructed, an aspiring scientist looks up and to practicing scientists. The argument is that it is difficult for underrepresented groups to see science positively and aspire to science professions when content and illustrations in science texts focus mainly on whites. One of the most important factors in discouraging minority youth in science involves teachers and teaching styles (Hanson, 2009). Lack of women scientists in the classroom and textbooks must be addressed and interactions with actual scientists can help young women as their personal science identities are forming.

Despite these difficulties and variations on different periods of one's academic life, many women of color persist and, at times, thrive in science. The notion that an individual's science identity is not predetermined and fixed lets us consider science identity across time and contexts. Students, in this case underrepresented girls, are not passive recipients of her life's conditions with little consideration for how they might creatively position themselves within and against those positions. The identity lens allows us to have different conversations about science learning at different phases of underrepresented girls' educational careers and to ask questions about the kinds of people promoted and marginalized by science environments at different points of their lives. The status quo of the dominant culture in which white middle class males dominate is no longer culturally relevant. Attracting underrepresented females to science is sort of like anti-bullying campaigns, if we want to create a culture without bullying we must focus on what we want- kindness. In the case of underrepresented women in science we must focus on little girls like Noa, who are accepted as scientists from the youngest of ages.

\section{References}

Angell, C., Henriksen, E., Isnes, K., \& Isnes, A. (2003). Why learn physics? Others can take care of that! Physics in Norwegian Education: Content-perceptions-choices. In D. Jorde \& B. Bungum (Eds.), Science Education Perspectives, Research \& Development Oslo: Akademisk (pp. 165-198).

Archer, L., Dewitt, J., Osborne, J., Dillion, J., Willis, B., \& Wong, B. (2013). “Doing” science versus "Being" a scientist: Examining 10/11-year-old schoolchildren's constructions of science through the lens of identity. Science Education, 94(4), 617-639. http://dx.doi.org/10.1002/sce.20399

Barman, C. (1997). Students' views of scientists and science: Results from a national study. Science and Children, 35(1), 18-23.

Brickhouse, N. W., \& Potter, J. T. (2001). Young women's science identity formation in an 
urban context. Journal of Research in Science Teaching, 38(8), 965-980. http://dx.doi.org/10.1002/tea.1041

Brickhouse, N. W., Lowery, P., \& Schultz, K. (2000). What kind of a girl does science? The construction of school identities. Journal of Research in Science Teaching, 37, 441-458. http://dx.doi.org/10.1002/(SICI)1098-2736(200005)37:5\%3C441::AID-TEA4\%3E3.0.CO;23

Buck, G., Plano, C. V., Leslie-Pelecky, D., Lu, Y., \& Cerda-Lizarraga, P. (2007). Examining the cognitive processes used by adolescent girls and women scientists in identifying science role models: A feminist approach. Science Education, 92(4), 688-707. http://dx.doi.org/10.1002/sce.20257

Cadinu, M., Maass, A., Rosabianca, A., \& Kiesner, J. (2011). Why do women underperform under stereotype threat threat? Evidence for the role of negative thinking. Psychological Science, 16, 572-578. http://dx.doi.org/10.1111/j.0956-7976.2005.01577.x

Carlone, H. B. (1994). The cultural production of science in reform-based physics: Girls' access, participation, and resistance. Journal of Research in Science Teaching, 37(8), 871-889.

Carlone, H. B., \& Johnson, A. (2007). Understanding the science experiences of successful women of color: Science identity as an analytic lens. Journal of Research in Science Teaching, 44(8), 1187-1218. http://dx.doi.org/10.1002/tea.20237

Chambers, D. W. (1983). Stereotypic images of the scientist: The Draw-a-Scientist Test. Science Education, 67(2), 255-265. http://dx.doi.org/10.1002/sce.3730670213

Clewell, B. C., \& Anderson, B. (1991). Women of color in mathematics, science, and engineering: A review of the literature. Washington, D.C.: Center for Women Policy Studies.

Cobb, J. P. (1993). A life in science: Research and service. In C. Fort, J. Bird \& J. Didion (Eds.), A Hand Up: Women Mentoring Women in Science. Washington, D.C.: The Association for Women in Science.

Eckert, P., \& McConnnell-Ginet, S. (2003). Language and gender. New York: Cambridge University Press. http://dx.doi.org/10.1017/CBO9780511791147

Eisenhart, M., Finkel, E., \& Marion, S. (1996). Creating conditions for scientific literacy: A re-examination. American Educational Research Journal, 33, 261-295. http://dx.doi.org/10.3102/00028312033002261

Erb, T. O. (1981). Attitudes of early adolescents toward science, women in science, and science careers. In T. O. Erb (Eds.), Middle School Research: Selected Studies (pp. 108-118).

Farland, D. (2006). Effect of historical, non-fiction, trade books on elementary students' perceptions of scientists. Journal of Elementary Science Education, 18(2), 33-50. http://dx.doi.org/10.1007/BF03174686

Farland-Smith, D. (2009). Stereotypes, cultures \& scientists: A cross-national comparative 
study of eastern \& western elementary students' perceptions of scientists. Journal of Elementary Science Education, 4(21). http://dx.doi.org/10.1007/BF03182355

Farland-Smith, D. (2012). Personal \& social interactions between young girls and scientists: Examining critical aspects for identity construction. Journal of Science Teacher Education, 23(1), 1-18. http://dx.doi.org/10.1007/s10972-011-9259-7

Finson, K. D. (2002). A multicultural comparison of draw-a-scientist test drawings of eighth graders. Paper presented at the Annual International Conference of the Association of Educators of Teachers of Science; Charlotte, NC.

Fort, D. C., \& Varney, H. L. (1989). How students see scientists: Mostly male, mostly white, mostly benevolent. Science \& Children, 26(8), 8-13.

Gettys, L., \& Cann, A. (1981). Children's perceptions of occupational sex stereotypes. Sex Roles, 7(3), 301-308. http://dx.doi.org/10.1007/BF00287544

Giddens, A. (1991). Modernity and self-identity. Self and society in the late modern age. Cambridge: Polity Press.

Glenn, C. (2004). Unspoken: A rhetoric of silence. Carbondale, IL: Southern Illinois University Press.

Hanson, S. L. (1996). Lost talent: Women in the sciences. Philadelphia: Temple University Press.

Hanson, S. L. (2004). African American women in science: Experiences from high school through post-secondary years and beyond. National Women's Studies Association Journal, 16(1), 96-115. http://dx.doi.org/10.2979/nws.2004.16.1.96

Hanson, S. L. (2009). Swimming against the tide. Philadelphia, PA: Temple University Press.

Hanson, S. L., \& Palmer-Johnson, E. (2000). Expecting the unexpected: A comparative study of African American women's experiences in science during the high school years. Journal of Women and Minorities in Science and Engineering, 6(4), 265-294. http://dx.doi.org/10.1615/JWomenMinorScienEng.v6.i4.10

Hoyte, R. M., \& Collett, J. (1993). "I can do it": Minority undergraduate science experiences and the professional career choice. In J. Gainen \& R. Boice (Eds.), Building a Diverse Faculty (pp. 81-91). San Francisco: Jossey-Bass. http://dx.doi.org/10.1002/t1.37219935310

Johnson, A. C. (2001). Women, race and science: The academic experiences of twenty women of color with a passion for science. University of Colorado, Boulder.

Lave, J., \& Wenger, E. (1991). Situated learning: Legitimate peripheral participation. Cambridge, England: Cambridge University Press. http://dx.doi.org/10.1017/CBO9780511815355

Lewis, M. (2003). Without a word: Teaching beyond women's silence. London: Routledge. Lindahl, B. (2003). A desire to learn science and technology: A longitudinal study of 
pathways to upper secondary school (Doctoral Thesis). Goteborg Studies in Educational Sciences, Goteborg.

Lyng, S. T. (2004). To learn or not to learn? On student roles, identity and learning in lower secondary school. Oslo: Universities forlaget.

Maple, S. A., \& Stage, F. K. (1991). Influences on the choice of math/science major by gender and ethnicity. American Educational Research Journal, 28(1), 37-60. http://dx.doi.org/10.3102/00028312028001037

Mau, W., Domnick, M., \& Ellsworth, R. A. (1995). Characteristics of female students who aspire to science and engineering or homemaking occupations. The Career Development Quarterly, 43(4), 323-337. http://dx.doi.org/10.1002/j.2161-0045.1995.tb00437.x

Mead, M., \& Metraux, R. (1957). The image of the scientist amongst high school students. In B. Barbar \& W. Hirsch (Eds.), The Sociology of Science (pp. 38-61). Lewes, England: Falmer Press.

National Center for Education Statistics. (2009). NAEP High school transcript study 2009. Washington, DC: US Department of Education.

National Science Board. (2010). Science and engineering indicators 2010. Arlington, VA: National Science Foundation (NSB 10-01).

National Science Board. (2014). Science and Engineering Indicators 2014. Arlington, VA (NSB 14-01).

Nespor, J. (1994). Knowledge in motion: Space, time and curriculum in undergraduate physics and management. Washington, DC: Falmer Press.

Newton, L. D., \& Newton, D. P. (1998). Primary children's perceptions of science and the scientist: Is the impact of a national curriculum breaking down the stereotype? International Journal of Science, 20(9), 1137-1149.

Ovelton Sammons, V. (1990). Blacks in science and medicine. Washington, D.C.: Hemisphere Publishing Corp.

Pearson, W. Jr. (1986). Black American participation in American science: Winning some battles but losing the war. Journal of Educational Equity and Leadership, 6(1), 45-59.

Russell, M. L., \& Atwater, M. M. (2005). Traveling the road to success: A discourse on persistence throughout the science pipeline with African American students at a predominately white institution. Journal of Researching in Science Teaching, 42, 691-715. http://dx.doi.org/10.1002/tea.20068

Sadker, D., Sadker, M., \& Zittleman, K. (2009). Still failing at fairness: How gender bias cheats boys and girls in school and what we can do about it. New York, NY: Simon and Schuster.

Sadowski, M. (2003). Why identity matters at school. In M. Sadowski (Ed.), Adolescents at 
School: Perspectives on Youth, Identity, and Education (pp. 1-5). Boston: Harvard Education Press.

Scantlebury, K., \& Kahle, J. B. (1993). The implementation of equitable teaching strategies by biology student teachers. Journal of Research in Science Teaching, 30(6), 537-545. http://dx.doi.org/10.1002/tea.3660300603

Schibeci, R. A., \& Sorenson, I. (1983). Elementary school children's perceptions of scientists. School Science Mathematics, $\quad$ 83(1), 14-19. http://dx.doi.org/10.1111/j.1949-8594.1983.tb10087.x

Schreiner, C., \& Joberg, S. (2007). Science education and young people's identity construction-two mutally incompatible projects? In D. Corrigan, J. Dillon \& R. Gunstone (Eds.), The Re-emergence of values in the science curriculum. Rotterdam: Sense Publishers.

Shenell Bolden, L. T. (2010). Noah the little scientist. Smashwords Edition: ebook.

Steele, C. M., \& Aronson, J. (1995). Stereotype threat and the intellectual test performance of African Americans. Journal of Personality and Social Psychology, 69, 797-811. http://dx.doi.org/10.1037/0022-3514.69.5.797

Storen, L. A., \& Arneson, C. A. (2003). A gender divided educational system. In M. Raabe, P. Aasen, P. O. Aamodt, N. M. Stolen, \& A. H. Hoisak (Eds.), Education 2003-resources, recruitment and results. Oslo: Statistik Sentralbyra, Statistics Norway.

Swarat, S., Drane, D., Smith, H. D., Light, G., \& Pinto, L. (2004). Opening the gateway: Increasing minority student retention in introductory science courses. Journal of College Science Teaching, 18-23.

Tan, E., \& Calabrese-Barton, A. (2007). From peripheral to central, the story of Melanie's metamorphosis in an urban middle school science class. Science Education, 92(4), 567-590. http://dx.doi.org/10.1002/sce.20253

Tan, E., \& Calabrese-Barton, A. (2008). Unpacking science for all through the lens of identities-in-practice. Cultural Studies of Science Education, 3, 43-71. http://dx.doi.org/10.1007/s11422-007-9076-7

Tan, E., Calabrese-Barton, A., Kang, H., \& O’Neil, T. (2013). Desiring a career in STEM-related fields: How middle school girls articulate and negotiate identities-in-practice. Journal of Research in Science Teaching, 50(10), 1143-1179. http://dx.doi.org/10.1002/tea.21123

Tannen, D. (1994). Gender and discourse. New York: Oxford University Press.

Thomas, A. (2007). Gendered, racial socialization among African American mothers and their daughters. Family Journal, 15(2), 137-142. http://dx.doi.org/10.1177/1066480706297853

Tomasetto, C., Alparone, F. R., \& Cadinu, M. (2011). Girls' math performance under stereotype threat: Moderating role of mothers' gender stereotype. Developmental Psychology, 47(4), 943-949. http://dx.doi.org/10.1037/a0024047 


\section{Macrothink}

Journal of Educational Issues

ISSN 2377-2263 2015, Vol. 1, No. 1

Vining Brown, S. (1994). Minority women in science and engineering education: Final report. Princeton, N.J.: Educational Testing Service.

Von Sentima, I. (1985). Blacks in science: Ancient and modern. New Brunswick, N.J.: Transition Books.

\section{Copyright Disclaimer}

Copyright for this article is retained by the author(s), with first publication rights granted to the journal.

This is an open-access article distributed under the terms and conditions of the Creative Commons Attribution license (http://creativecommons.org/licenses/by/3.0/). 